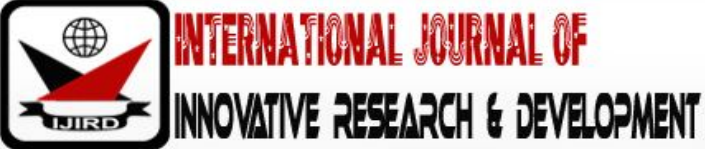

ISSN 2278 - 0211 (Online)

\section{The Effect of Macro Economics on Indeks Harga Saham Gabungan (IHSG) in Indonesia Stock Exchange (IDX) Period 2007-2016}

\author{
Dr. Didin Fatihudin \\ Lecturer Department of Economics and Business Faculty, \\ Muhammadiyah University Surabaya, Indonesia \\ Dr. Muhammad Anang Firmansyah \\ Lecturer, Department of Economics and Business Faculty, \\ Muhammadiyah University Surabaya, Indonesia
}

\begin{abstract}
:
Macroeconomics changes in Indonesia will affect the Indonesian economy and all existing industries. The capital market becomes a driver of the national economy through its role as a source of corporate finance and an alternative for investors to invest. In the capital market, the Indeks Harga Saham Gabungan (IHSG) plays an important role because this index can be a barometer of economic health in a country. The high inflation, interest rates and depreciation of the rupiah against the dollar will reduce share prices. This study aims to see the effect of macroeconomic factors, namely inflation, exchange rates and interest rates on the Indeks Harga Saham Gabungan (IHSG) on the Indonesia Stock Exchange (IDX). The analysis method uses multiple linear analysis models. The data used in this study are monthly data for the period January 2007December 2016. This study uses a sample of 100 samples. The results it is concluded that the inflation variable has a positive and significant effect on the Indeks Harga Saham Gabungan (IHSG). The exchange rate variable has a positive and significant effect on the Indeks Harga Saham Gabungan (IHSG). The interest rate variable has a negative and significant effect on the Indeks Harga Saham Gabungan (IHSG). Simultaneously the independent variables, namely inflation, exchange rates and interest rates have a significant influence on the Indeks Harga Saham Gabungan (IHSG)
\end{abstract}

Keywords: Inflation, exchange rate, interest rate, IHSG

\section{Introduction}

Macroeconomic changes in Indonesia will certainly affect the national economy and the entire industry. For example, high inflation and the weakening of the rupiah will make many industries experience shocks, declining production due to rising prices of raw materials which results in a decrease in the level of profit. With the decline in the level of profit will certainly have an impact on the decline in stock prices in the industry because dividends that will be received by shareholders will decrease so that many investors will withdraw their investment. Rising interest rates will make investors more interested in investing in bank savings rather than investing in the capital market. The decline in stock prices in the industry will also have an impact on the decline in the Indeks Harga Saham Gabungan (IHSG) on the Indonesia Stock Exchange (IDX). Macroeconomics does not affect company performance instantly but slowly and over a long period of time. Conversely, stock prices will be affected immediately by changes in macroeconomic factors because investors react faster. When macroeconomic changes occur, investors will take into account the positive and negative impacts on the company's performance in the next few years, then make the decision to buy, sell or hold the shares in question (Samsul, 2006). Therefore, the stock price index adjusts more quickly to changes in macroeconomic variables than the performance of the company concerned. In theory, high inflation causes a decrease in the purchasing power of money and reduces the level of real income that investors get from their investments. High interest rates will also affect the present value of the company's cash flow, so that the investment opportunities that exist will not be attractive anymore. Depreciation of the domestic currency against foreign currencies makes investors reluctant to invest in the capital market because the depreciation of the domestic currency against foreign currencies or the depreciation of the rupiah against the USD indicates that the prospects of the Indonesian economy are bad and the causes of weakening of the exchange rate may strong so that the value of the USD strengthens and will reduce the Indeks Harga Saham Gabungan (IHSG). 


\section{Literature Review and Hypothesis}

Macroeconomics or macroeconomics is part of economics that studies overall economic problems (aggregative). Macroeconomics studies the economic conditions of a society / country such as unemployment, employment opportunities, State expenditure, national income, interest rates, exchange rates / exchange rates, and so on.

\subsection{Inflation}

According to Sukirno (2003), the increase in general prices or inflation is caused by three factors, namely the money supply, the speed of circulation of money, and the amount of goods traded. According to him inflation is the process of raising prices of general goods that apply in the economy. This does not mean that the prices of various items rise by the same percentage. The important thing is that there is a continuous increase in the general prices of goods for a certain period. The increase that occurs only once (even with a large percentage) is not inflation. Veneris and Sebol in Muana Nanga (2001) define inflation as the trend of increasing general price levels continuously all the time. Based on this definition, the general price level increases happen once, it cannot be said as inflation. Bambang and Aristanti, (2007) Inflation according to Bambang and Aristanti is a continuous process of increasing general prices. The incidence of inflation will result in a decline in people's purchasing power. This happens because in inflation there will be a decrease in income level. One example in a country the better the marketing strategy carried out by Warung Giras in Surabaya, the customers will be satisfied and the number of customers will increase for the future in this case it can be an indicator to reduce inflation in Indonesia (Firmansyah, A., \& Mochklas, M. 2018).

\subsection{Exchange Rate}

Exchange rate is a value that shows the amount of domestic currency value needed to obtain a unit of foreign currency (Sukirno, 2003). The exchange rate is one of the most important prices in an open economy given the significant influence on the current account balance and other macroeconomic variables. There are two approaches that are used to determine currency exchange rate, namely the monetary approach and the market approach. In the monetary approach, currency exchange rates are defined as prices where foreign currencies are traded against the domestic currency and those prices are related to money supply and demand. The theory of determining exchange rate movements was initially developed by Keynesian supporters, like Harberger Laursen and Metzler and Alexander. Most of these studies focus on the importance of demand elasticity supply of exports and imports, foreign currency demand and supply, and conditions where a devaluation may be effective in increasing balance trading.

\subsection{Interest Rate}

According to Hubbard (2005), interest rate are the costs that must be paid by the borrower for the loan received and the reward for the lender for his investment. According to Karl and Fair (2001), interest rates are annual interest payments from a loan, in the form of a percentage of loans obtained from the amount of interest received each year divided by the number of loans. Definition of interest rates according to Sunariyah (2004) is the price of a loan. Interest rates are expressed as a percentage of principal per unit of time. Interest is a measure of the price of resources used by debtors that must be paid to creditors. There is an increase in production efficiency, so that the expected profits increase so that at the same interest rate entrepreneurs are willing to pay more funds to finance investments, or for the same amount of investment funds, entrepreneurs are willing to pay a higher interest rate. This situation is indicated by the shifting of the investment demand curve to the upper right, so that the balance of the new interest rate (Nopirin, 1993).

\subsection{Indeks Harga Saham Gabungan (IHSG)}

According to Sunariyah (2006) the combined stock price index of all shares describes a series of historical information regarding the movement of the combined stock price of all shares, up to a certain date. Usually the stock price movements are presented every day, based on the closing price on the exchange on that day. The index is presented for a certain period. The increase in the number of outstanding shares comes from new emissions, namely the entry of new issuers listed on the Stock Exchange, or corporate action in the form of split, right, warrants, stock dividends, bonus shares, and convertible shares. Growth in the ability to generate profits, not sales per unit, which is the goal want to be achieved. (Sari, I., Firmansyah, M. A., \& Mahardhika, B. W. 2016). Observation of the relationship between stocks and exchange rates has broad implications in explaining the behavior of a market through information / events that occur in other markets, Roisondo dan Dias (2015).

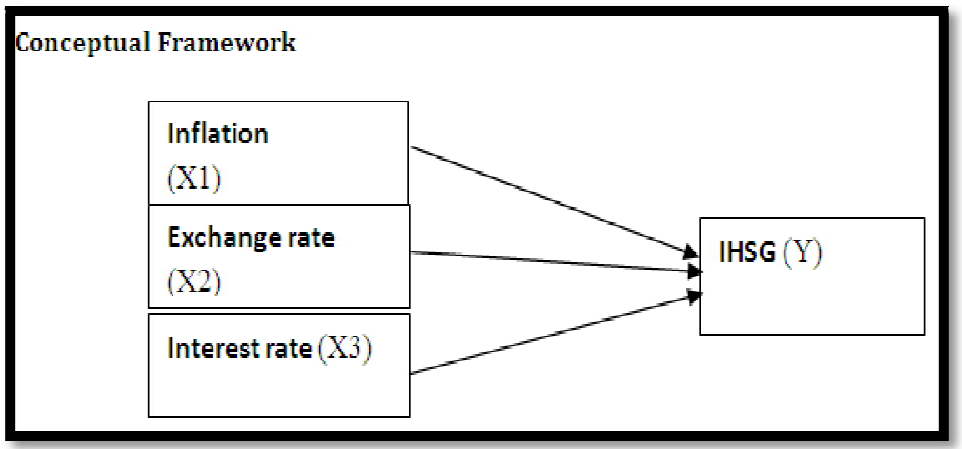

Figure 1 
Based on the background of the problems described previously, four research issues can be formulated as follows:

- Does Inflation effect on Indeks Harga Saham Gabungan (IHSG)?

- Does Exchange rate effect on Indeks Harga Saham Gabungan (IHSG)?

- Does Interest rate effect on Indeks Harga Saham Gabungan (IHSG)?

2.5. Hypothesis

- The hypothesis (H1) is: "Inflation effect on Indeks Harga Saham Gabungan (IHSG)?"

- The hypothesis (H2) is:"Exchange rate effect on Indeks Harga Saham Gabungan (IHSG)?"

- $\quad$ The hypothesis (H3) is:"Interest rate effect on Indeks Harga Saham Gabungan (IHSG)?"

\section{Research Methods}

The type of research used is the type of associative research. This study aims to test the existing hypotheses based on the theories that have been formulated and obtained from the company in the form of numbers calculated further by a quantitative approach. The population in this study includes data on inflation rates, exchange rates, interest rates and the Indeks Harga Saham Gabungan (IHSG)The sample in this study is monthly data from January 2007 to December 2016 with a total of 100 samples from data on inflation rates, exchange rates, interest rates and the Indeks Harga Saham Gabungan (IHSG).

The data used in this study are Indonesian inflation data, the rupiah exchange rate against the US dollar, Indonesian interest rates and the Indeks Harga Saham Gabungan (IHSG) of the last 10 years of data every month from January 2007 to December 2016. Data sources are obtained from the Bursa official website Indonesian Securities. The data collection technique in this study is the documentation method, which is taking documents in the form of inflation value, USD / IDR exchange rate, interest rate and the Indeks Harga Saham Gabungan (IHSG). The analytical method used to test the hypothesis is a multiple linear regression analysis model. Multiple regression is a regression equation using two or more independent variables. (Fatihudin, D., 2015). Multiple regression analysis in this study was used to determine the effect of inflation, exchange rates and interest rates on the Indeks Harga Saham Gabungan (IHSG) on the Indonesia Stock Exchange (IDX).

\section{Research Result and Discussion}

\subsection{Multicollinearity Test}

To detect the presence or absence of multi collinearity in a regression model can be seen from tolerance value or variance inflation factor (VIF). The VIF limit is 10 if the VIF value is greater than 10 (VIF>10) then multicollinearity occurs. The table above shows that the three independent variables, namely inflation, exchange rates and interest rates have a variance inflation factor (VIF) value of less than 10 . So, it can be concluded that there is no multicollinearity between independent variables in the regression model.

\begin{tabular}{|c|c|c|c|}
\hline \multicolumn{4}{|c|}{ Coefficients ${ }^{\mathbf{a}}$} \\
\hline \multirow{2}{*}{\multicolumn{2}{|c|}{ Model }} & \multicolumn{2}{|c|}{ Collinearity Statistics } \\
\hline & & Tolerance & VIF \\
\hline \multirow[t]{4}{*}{1} & (Constant) & & \\
\hline & Inflation & .292 & 3.421 \\
\hline & Exchange & .996 & 1.004 \\
\hline & Interest rates & 292 & 3.428 \\
\hline
\end{tabular}

Table 1: Multicollinearity Test

a. Dependent Variable: IHSG

\subsection{F Test}

The test criteria if the value of Fcount $\leq$ Ftable means that all the independent variables used do not significantly influence the dependent variable. If Fcount $\geq$ Ftable means that all independent variables have a significant effect on the dependent variable with a level of 0.05 .

\begin{tabular}{|c|c|c|c|c|c|c|}
\hline \multicolumn{2}{|c|}{ Model } & $\begin{array}{c}\text { Sum of } \\
\text { Squares }\end{array}$ & df & $\begin{array}{c}\text { Mean } \\
\text { Square }\end{array}$ & F & Sig. \\
\hline \multirow{2}{*}{1} & Regression & $1.257 \mathrm{E} 8$ & 3 & $4.190 \mathrm{E} 7$ & 65.313 & $.000 \mathrm{a}$ \\
\cline { 2 - 7 } & Residual & $7.441 \mathrm{E} 7$ & 116 & 641469.417 & & \\
\cline { 2 - 7 } & Total & $2.001 \mathrm{E} 8$ & 119 & & & \\
\hline
\end{tabular}

Table 2: F Test

a. Predictors: (Constant), Interest Rates, Exchange Rates, Inflation

b. Dependent Variable: IHSG 
The table above shows the Fcount value of 65,313 with a significance level below $5 \%$ or 0.05 , while the $\mathrm{F}$ table is 2.683 which means that $\mathrm{F}$ count $>\mathrm{F}$ table. This means that $\mathrm{H} 0$ is rejected and $\mathrm{H} 4$ is accepted. From the results of the $\mathrm{F}$ test it can be concluded that the independent variables namely inflation, exchange rates and interest rates together / simultaneously have a significant effect on the dependent variable, namely the Interest rates effect on Indeks Harga Saham Gabungan (IHSG) on the Indonesia Stock Exchange (IDX).

\subsection{T Test}

The $t$ test is carried out with the aim to test the significance of the effects of the independent variables namely inflation, exchange rate and interest rates partially / individually on the dependent variable, the Indeks Harga Saham Gabungan (IHSG).

\begin{tabular}{|c|c|c|c|c|c|c|}
\hline \multicolumn{2}{|c|}{ Model } & \multicolumn{2}{|c|}{$\begin{array}{c}\text { Unstandardized } \\
\text { Coefficients }\end{array}$} & $\begin{array}{c}\text { Standardized } \\
\text { Coefficients }\end{array}$ & & \multirow{2}{*}{} \\
\cline { 3 - 5 } \multicolumn{2}{|c|}{} & B & Std. Error & Beta & t & Sig. \\
\hline \multirow{2}{*}{1} & (Constant) & 3321.62 & 658.293 & & 5.046 & .000 \\
\cline { 2 - 7 } & Inflation & 8802.84 & 4136.775 & .223 & 2.128 & .035 \\
\cline { 2 - 7 } & Exchange & .392 & .049 & .451 & 7.953 & .000 \\
\cline { 2 - 7 } & Interest rates & - & 7814.983 & -.802 & -7.653 & .000 \\
\hline
\end{tabular}

Table 3: T Test

Based on the table above inflation produces a value of $t$ count of 2.128 while $t$ table of 1.981 which means t count $\geq t$ table and this variable has a significance level of 0.034 which when compared with the predetermined degree of error of $5 \%$ or 0.05 , the significance value of inflation is smaller than degree error. The inflation regression coefficient (X1) is 8802,842 positive. This means that $\mathrm{H} 0$ is rejected and $\mathrm{H1}$ is accepted. From the results of the test it was concluded that inflation has a positive and significant influence on the Indeks Harga Saham Gabungan (IHSG) on the Indonesia Stock Exchange (IDX).

Exchange rate produces a t count of 7.953 while $t$ table is 1.981 which means $t$ count $\geq t$ table and this variable has a significance level of 0.000 which when compared with the predetermined degree of error is $5 \%$ or 0.05 , the value of variable exchange rate is smaller than the degree of error. The exchange rate regression coefficient (X2) is 0.392 positive. This means that $\mathrm{H} 0$ is rejected and $\mathrm{H} 2$ is accepted. From the results of the $t$ test it was concluded that the exchange rate had a positive and significant effect on the Indeks Harga Saham Gabungan (IHSG) on the Indonesia Stock Exchange (IDX).

Interest rates yield $t$ value of 7.653 while $t$ table is 1.981 which means $t$ count $\geq t$ table and this variable has a significance level of 0.000 which when compared with the predetermined degree of error is $5 \%$ or 0.05 , variable significance value of interest rate is smaller than degree error. The interest rate regression coefficient (X3) is -59810,957 negative value. This means that $\mathrm{H} 0$ is rejected and $\mathrm{H} 3$ is accepted. From the results of the test it is concluded that the interest rate has a negative and significant effect on the Indeks Harga Saham Gabungan (IHSG) on the Indonesia Stock Exchange (IDX).

\section{Conclusion}

In accordance with the formulation of the problem and the purpose of the research and the results of the analysis that has been carried out, the following conclusions can be drawn:

- Inflation has a positive and significant influence on the Indeks Harga Saham Gabungan (IHSG) on the Indonesia Stock Exchange (IDX).

- Exchange rate have a positive and significant influence on the Indeks Harga Saham Gabungan (IHSG) on Indonesia Stock Exchange (IDX).

- Interest rate have a negative and significant influence on the Indeks Harga Saham Gabungan (IHSG) on the Indonesia Stock Exchange (IDX).

- Inflation, exchange rate and interest rate together or simultaneously have a significant influence on the Indeks Harga Saham Gabungan (IHSG) on the Indonesia Stock Exchange (IDX).

This research is expected to contribute to the development of further researchers. Based on existing limitations, it is expected that further researchers can consider the following:

- Add elements of the research variable so that other factors can influence the Indeks Harga Saham Gabungan (IHSG).

- Increase the number of samples that will be used in the study

\section{References}

i. Bambang Widjajanta, Aristanti Widyaningsih. (2007). Mengasah Kemampuan Ekonomi. Citra Praya, Bandung.

ii. Fatihudin, D. (2015). Metodologi Penelitian Untuk Ilmu Ekonomi, Manajemen dan Akuntansi dari Teori ke Praktek . Sidoarjo: PT Zifatma.

iii. Fatihudin, D. (2015). Analysis of Factors Affecting Consumer Decisions Buy Motorcycle Jurnal Ekonomi. 
iv. Firmansyah, M. A., \& Mahardhika, B. W. (2018). PENGARUH FAKTOR-FAKTOR LINGKUNGAN KERJA INTERNAL DAN PEKERJAAN TERHADAP MOTIVASI KERJA KARYAWAN PADA PT. WARNATAMA CEMERLANG GRESIK. Balance, 15(02).

v. Firmansyah, A., \& Mochklas, M. (2018). ANALISA STRATEGI PRODUK, HARGA, PROMOSI DAN TEMPAT TERHADAP KEPUASAN PELANGGAN WARUNG GIRAS DI SURABAYA. JURNAL EKSEKUTIF, 15(1), 281-295.

vi. Hubbard, R. Glenn. (2005). Money, the Financial System, and the Economy. 5th Ed., Personal Education, USA.

vii. Karl, E Case dan Fair, C Rai. (2001). Prinsip-prinsip Ekonomi Makro. Prenhalindo, Jakarta.

viii. Kewal Suramaya, (2012). Pengaruh Inflasi, Suku Bunga, Kurs, dan Pertumbuhan PDB terhadap Indeks Harga Saham Gabungan. Jurnal Economia. Volume 8, Nomor 1

ix. $\quad$ Muana, Nanga. (2001). Makro Ekonomi, Teori, Masalah dan Kebijakan. Edisi Perdana. Jakarta: PT. Raja Grafindo Persada.

x. Nopirin. (1993). Ekonomi Moneter II. BPFE : Yogyakarta.

xi. Roisondo dan Dias. (2015). Analisis Pengaruh Indikator Makroekonomi Dan Indeks Harga Saham Regional ASEAN Terhadap Pasar Saham Indonesia (IHSG) Periode Pada Tahun 2009-2014. Jurnal Ilmiah. Universitas Brawijaya Malang.

xii. Sari, I., Firmansyah, M. A., \& Mahardhika, B. W. (2016). PENGARUH PERTUMBUHAN PENJUALAN DAN RETURN ON EQUITY TERHADAP PERUBAHAN LABA PADA PERUSAHAAN PERTAMBANGAN BATU BARA YANG TERDAFTAR DI BURSA EFEK INDONESIA TAHUN 2010-2015. Balance, 13(01).

xiii. Sukirno, Sadono. (2003). Pengantar Teori Makro Ekonomi. Edisi kedua, PT. Raja Grafindo Persada, Jakarta.

xiv. Sunariyah. (2006). Pengantar Pengetahuan Pasar Modal. Edisi kelima, UPP, Yogyakarta 